\title{
Giving Due Consideration
}

\author{
A Normative Pathway between UN Human Rights \\ Treaty-Monitoring Bodies and Domestic Courts
}

MACHIKO KANETAKE

\subsection{Introduction}

Human rights law is one of the fields of law that creates the subject matter overlap between international and domestic law. Human rights treaties purport to regulate the governmental authority exercised over individuals, which is, in parallel, regulated by domestic constitutional and administrative law. This overlap creates the deliberative space between human rights treaty-monitoring bodies and national authorities, including domestic courts. In fact, judicial decisions can be at times 'entangled' with the findings of UN human rights treaty-monitoring bodies. Domestic courts take note, discuss, accept or resist decisions, comments or observations of UN human rights treaty-monitoring bodies. The quality of such a deliberative space is crucial for the effectiveness of the treaty-monitoring bodies, whose findings ultimately aim at bringing about change to domestic legal frameworks and practices, including those of the judiciary.

Against this background, this chapter engages in the analysis of pathways that guide the deliberative space involving UN human rights treatymonitoring bodies and domestic courts. Such pathways can be pragmatic or sociological in nature. For instance, the unavailability of treaty body findings in local languages significantly limits public knowledge about them and the likelihood that litigant parties rely on general comments and other treaty body findings. Interactions can be facilitated if judges periodically receive training regarding the work of the monitoring bodies. At the same time, domestic judges' interactions with treaty body findings have also been guided by normative pathways. They can originate in both international and national law. In limited circumstances, such pathways exhibit a formalistic character that Views, one of the categories of the 
documents produced by treaty bodies, have legal binding force. Yet it is usually the case that normative pathways are much less dichotomous.

This chapter examines one of such normative pathways, namely that state parties ought to give due consideration to the findings of UN human rights treaty-monitoring bodies. The legal basis of such a duty to consider remains contested. Furthermore, the duty to consider is necessarily precarious, inasmuch as its effectiveness depends on how precisely consideration is given by judges in a particular case. Nevertheless, the duty to consider - and its normative variations, as will be discussed in this chapter - occasionally appears in the reasoning of domestic courts whose narrative is entangled with treaty interpretation by UN human rights-monitoring bodies.

The chapter starts by outlining the different types of the findings of the monitoring bodies (Section 6.2). Domestic courts' engagement varies depending on states, courts and judges. The limited research I have conducted $^{1}$ demonstrates a great deal of variance with regard to domestic courts' explicit engagement with the monitoring bodies. Domestic judges may not be aware of the relevant documents; and even if they are, they may reject the judicial relevance of such documents (Section 6.3). At the same time, there are a number of domestic court decisions that have explicitly invoked treaty body findings (Section 6.4). What matters for the sake of this chapter is that judicial engagement can be guided by the duty to consider and its variations (Sections 6.4 and 6.5). These pathways serve as 'interface norms' that facilitate ties yet preserve discretion on the part of domestic courts. ${ }^{2}$ Under limited circumstances, the duty to consider may even be understood as entailing an obligation to give effect to Views (Section 6.6). The duty to consider may not be a robust normative path. Yet it can still pave the way for a sustainable and forward-looking deliberative space, by creating the opportunities for learning and selfreflection for domestic courts and the international guardians.

1 The chapter's analysis is based on my previous publication: M. Kanetake, 'UN Human Rights Treaty Monitoring Bodies before Domestic Courts' (2018) 67 International \& Comparative Law Quarterly 201-32. For the sake of the previous publication, I have collected and analysed 150 domestic court decisions (decided from 1982 to 2016) across forty-one jurisdictions. For the sake of the present chapter, I have additionally collected and analysed forty other domestic court decisions (decided between 1992 and 2018) across twenty-one jurisdictions, based on my own research, existing literature, the Oxford Reports on International Law in Domestic Courts (ILDC) and the International Law Reports (ILR).

2 See Chapter 1. 


\subsection{Measuring the Domestic Relevance of the 'Jurisprudence' of the Monitoring Bodies}

UN human rights treaty-monitoring bodies are part of the institutional arrangements at the international level that assist states' implementation of nine core human rights treaties. There are ten bodies tasked with monitoring the implementation of the treaties, namely: (1) Human Rights Committee (HRC), (2) Committee on Economic, Social and Cultural Rights (CESCR), (3) Committee on the Elimination of Racial Discrimination (CERD), (4) Committee on the Elimination of Discrimination against Women (CEDAW), (5) Committee Against Torture (CAT), (6) Subcommittee on Prevention of Torture, (7) Committee on the Rights of the Child (CRC), (8) Committee on Migrant Workers (CMW), (9) Committee on the Rights of Persons with Disabilities (CRPD), and (10) Committee on Enforced Disappearances (CED). These committees have been adjusting their working methods towards better harmonization, particularly in response to the UN General Assembly's resolution 68/268 of 2014 . $^{3}$

The ten bodies issue a wide range of documents (which are generally termed 'findings' in this chapter). They can be categorized into three types: ${ }^{4}$ (1) General Comments and Recommendations, which are addressed to all state parties; (2) Concluding Observations and Concluding Comments, which are addressed to a particular state party; and (3) Views (or Decisions) and Suggestions and Recommendations, which pertain to individual communications or petitions. ${ }^{5}$ There are eight treaty bodies that are competent to receive and consider petitions from individuals. ${ }^{6}$ By mobilizing the limited staff resources, the committees adopted 250 decisions on individual communications per year during 2018-19, for instance. ${ }^{7}$ In some of those decisions, the committees found breaches of treaty obligations. Between 1977 and March 2019,

${ }^{3}$ UN General Assembly, 'Strengthening and Enhancing the Effective Functioning of the Human Rights Treaty Body System' (21 April 2014) UN Doc. A/RES/68/268, para. 38.

${ }^{4}$ See N. Ando, 'General Comments/Recommendations', in R. Wolfrum (ed.), The Max Planck Encyclopedia of Public International Law (Oxford University Press, 2008), para. 2.

5 This chapter consistently uses the term 'Views' to describe the types of findings regarding individual communications or petitions, even if the findings can also be entitled as 'Decisions', etc.

6 These eight bodies are: HRC, CESCR, CERD, CEDAW, CAT, CRC, CRPD, and CED. The CMW also anticipates the petition mechanism.

7 Report of the Secretary-General, 'Status of the Human Rights Treaty Body System' (10 January 2020) UN Doc. A/74/643, para. 18. 
the HRC found violations of the International Covenant on Civil and Political Rights (ICCPR) in 1,157 Views. ${ }^{8}$ The adoption of Views is in addition to thirty-six General Comments adopted by the HRC between 1981 and 2018, accompanied by numerous state-specific observations.

The crux is that these different types of findings are cross-referenced with one another, which internally strengthens each body's treaty interpretation. ${ }^{9}$ Just to provide one specific example, in its Concluding Observations addressed to the Netherlands in 2016, the CEDAW urged the state party to implement its earlier Views, by further indicating that the state's non-implementation of the Views is inconsistent with the CEDAW's General Recommendation No. 33 on women's access to justice. $^{10}$ By cross-referencing its own documents, each treaty body creates what the International Court of Justice (ICJ) termed 'jurisprudence' in para. 66 of the Diallo case $(2010)^{11}$ - although, I must add, the use of such a juridical vocabulary depends on how one appreciates the functions of the treaty-monitoring bodies.

Para. 66 of the Diallo case is crucial in that the ICJ commented on the normative relevance of the HRC's treaty interpretation. The court observed that the HRC has 'built up a considerable body of interpretive case law' through Views and General Comments. ${ }^{12}$ Having reiterated the formalistic starting point that the court is 'in no way obliged' to follow the interpretation of the HRC, the court continued by saying that it 'should ascribe great weight to the interpretation' of the HRC. ${ }^{13}$ The Diallo case was not the first occasion on which the ICJ had resorted to the position of the HRC. ${ }^{14}$ Yet the remark of the court in Diallo was noteworthy, in that the court elucidated the normative 'weight' to be

8 UNHRC, 'Report of the Human Rights Committee, 123rd Session (2-27 July 2018), 124th Session (8 October-2 November 2018), 125th Session (4-29 March 2019)' (2019) UN Doc. A/74/40, para. 25.

9 See, on the CERD's work, R. Wolfrum, 'The Committee on the Elimination of Racial Discrimination' (1999) 3 Max Planck Yearbook of United Nations Law Online 489-519, at 509.

10 CEDAW, 'Concluding Observations on the Sixth Periodic Report of the Netherlands' (24 November 2016) CEDAW/C/NLD/CO/6, para. 14.

11 Ahmadou Sadio Diallo (Republic of Guinea v. Democratic Republic of the Congo), Merits, Judgment of 30 November 2010, [2010] ICJ Reports 639, para. 66.

12 Ibid., para. 66.

13 Ibid., para. 66 (emphasis added).

14 E.g., Legal Consequences of the Construction of a Wall in the Occupied Palestinian Territory, Advisory Opinion of 9 July 2004, [2004] ICJ Reports 136, paras 109-10. See L. Crema, 'The Interpretive Work of Treaty Bodies: How They Look at Evolutionary Interpretation, and How Other Courts Look at Them', in G. Abi-Saab et al. (eds), 
given to the HRC's interpretation. This does not mean that the ICJ is consistent in terms of its willingness to substantively engage with UN human rights treaty-monitoring bodies. In the Obligation to Prosecute or Extradite (Belgium v. Senegal) case (2012), the ICJ took a rather dismissive attitude towards the CAT's treaty interpretation. ${ }^{15}$

Methodologically, it is hard to assess the extent to which treaty body findings alter domestic legal practices. The international bodies' interpretation can influence legal discourse indirectly and over a long period of time. That said, one form of assessment is to measure the level of compliance. Some treaty-monitoring bodies indicate the level of satisfactory follow-up by states parties to the outcomes of individual communications. For example, the CAT's report of May 2017 shows that 42 per cent of its communications (55 out of 131), in which the CAT found violations, resulted in satisfactory or partially satisfactory outcomes. $^{16}$

Yet this chapter's focus is not on assessing general rates of compliance. Instead, the chapter analyses the explicit reference to treaty body findings in judicial reasoning. The cases I examine are therefore inclusive of, but not limited to, the case-specific responses to Views. This wider coverage is appropriate and necessary, precisely because the chapter's focus is on the judiciary, as opposed to other branches of the government. As I further explain in Section 6.3, domestic courts play a relatively limited role in providing case-specific responses to Views. The principle of res judicata often prevents judges from reopening cases at the domestic level. National courts may be able to give effect to Views if there are any relevant pieces of domestic law that allow judges to reopen a case. ${ }^{17}$ Illustrative in this regard is a Norwegian example. By the Act of 15 June 2001 No. 63 which amended the Criminal Procedure and the Civil Procedure Acts, Norway allowed the reopening of cases following the

Evolutionary Interpretation and International Law (Hart Publishing, 2019) p. 77-90, at p. 84.

15 Obligation to Prosecute or Extradite (Belgium v. Senegal), Judgment of 20 July 2012, [2012] ICJ Reports 422, para. 101. Cf. separate opinion of Judge Cançado Trindade at 551-2, paras 161-5.

${ }^{16}$ CAT, 'Report of the Committee against Torture, Fifty-eighth session (25 July-12 August 2016), Fifty-ninth session (7 November-7 December 2016), Sixtieth session (18 April-12 May 2017)' (2017) UN Doc. A/72/44, para. 87.

17 See R. van Alebeek and A. Nollkaemper, 'The Legal Status of Decisions by Human Rights Treaty Bodies in National Law', in H. Keller and G. Ulfstein (eds), UN Human Rights Treaty Bodies: Law and Legitimacy (Cambridge University Press, 2012) pp. 356-413, at pp. $360-82$. 
findings of the monitoring body. ${ }^{18}$ While the Norwegian initiatives have been welcomed by the HRC, ${ }^{19}$ few countries seem to have followed the same path that systematically allows the reopening of proceedings. This means that the case-specific responses to Views primarily depend on the willingness of the executive and legislative branches of the government. ${ }^{20}$

\subsection{Judicial Non-engagement}

\subsubsection{Domestic Courts' Practices}

As noted in Section 6.2, while the monitoring bodies adopt a number of general and country-specific findings, their practical relevance ultimately relies upon domestic acceptance. While it is methodologically challenging to have an overview of the practices of national courts' engagement with the monitoring bodies, the analysis of judicial decisions I have conducted ${ }^{21}$ provides some ideas about the patterns of engagement. To begin with, the pronouncement of the monitoring bodies has not been used as an independent and free-standing basis for the final decisions of domestic courts. Namely, Views, and much less General Comments and Concluding Observations, do not serve as the basis on which domestic courts decide the wrongfulness of acts or the legality of law.

In light of this, attempts to construe Views as an autonomous legal basis for judicial decisions have met with rejection. ${ }^{22}$ Illustrative in this regard is the Irish Supreme Court's decision in Kavanagh v. Governor of Mountjoy Prison (2002), ${ }^{23}$ forming a part of the case-specific response to the HRC's Views in which Ireland was found in breach of Article 26 of

18 UNHRC, 'Consideration of Reports Submitted by States Parties under the Covenant, Fifth Periodic Report, Norway' (3 December 2004) CPR/C/NOR/2004/5, para. 157. See also para. 158 (establishment of the Criminal Cases Review Commission to assist petitioners).

19 UNHRC, 'Concluding Observation of the Human Rights Committee, Norway' (25 April 2006) $\mathrm{CCPR} / \mathrm{C} / \mathrm{NOR} / \mathrm{CO} / 5$, para. 3(b) (establishment of the Commission to assist petitioners).

20 See, e.g., X v. Council of Ministers, Appeal judgment ILDC 2520 (ES 2015), ROJ: STS 507/ 2015, ECLI: ES:TS:2015:507 (Spain, Supreme Court, Administrative Chamber, 6 February 2015) paras 41-5 (OUP page numbers).

21 See n. 1 above.

22 See nn. 17-19 and accompanying text on the principle of res judicata and the need for specific pieces of legislation.

${ }^{23}$ Kavanagh v. Governor of Mountjoy Prison [2002] 3 IR 97; 132 ILR 380 (Ireland, Supreme Court, 1 March 2002) 404. 
the ICCPR on equality before the law. ${ }^{24}$ While the Irish Supreme Court's rejection was based on the constitutional ground that justice ought to be administered by properly constituted courts, ${ }^{25}$ the court also commented on the absence of international legal grounds. According to the Irish court, '[n] either the Covenant nor the Protocol at any point purports to give any binding effect to the views expressed by the Committee' which, as the Supreme Court reiterated, 'does not formulate any form of judgment or declare any entitlement to relief. ${ }^{26}$

In a similar vein, another noteworthy case is Wilson v. Ermita (2016) before the Supreme Court of the Philippines. ${ }^{27}$ In 1998, Wilson, a British national, was convicted of the crime of rape and sentenced to death. Before his conviction was set aside by the Supreme Court in $1999,{ }^{28}$ Wilson submitted the communication to the HRC, which eventually rendered its Views in $2003 .{ }^{29}$ According to the HRC, the conditions under which Wilson was arrested, detained and imprisoned infringed several provisions of the ICCPR, including Article 7 on the prohibition of torture, or other cruel, inhuman or degrading treatment or punishment. ${ }^{30}$ The HRC observed that the Philippines should provide compensation for Wilson. ${ }^{31}$ He then filed a petition for mandamus before the Supreme Court of the Philippines, arguing that the government is obliged to enforce the Views as part of its duties under international law. ${ }^{32}$ The Supreme Court dismissed Wilson's claim. While the court's rejection was based primarily on the lack of domestic effect of treaties, ${ }^{33}$ the Supreme Court made remarks on the characteristics of Views. According to the court, nowhere in the ICCPR does it state that Views formed part of the treaty. ${ }^{34}$

24

UNHRC, Kavanagh v. Ireland (No.1), Views, Communication No. 819/1998, CCPR/C/ 71/D/819/1998, adopted 4 April 2001, paras 10.3 and 11.

${ }^{25}$ Kavanagh v. Governor of Mountjoy Prison, 404 (referring to Article 34.1 of the Irish Constitution).

${ }^{26}$ Ibid.

27 Wilson v. Ermita and ors, Petition for mandamus, GR No 189220, ILDC 3005 (PH 2016) (Philippines, Supreme Court, 7 December 2016).

28 Ibid., paras 3-6 (paragraph numbers added by Oxford University Press (OUP)).

29 UNHRC, Albert Wilson v. The Philippines, Views, Communication No. 868/1999, CCPR/ C/79/D/868/1999 (11 November 2003).

${ }^{30}$ Ibid., paras 7.3-8 (violations of Articles 7, 9(1)-(3), 10(1)-(2)).

31 Ibid., para. 9.

32 Wilson v. Ermita, para. 17 (OUP numbers).

33 Ibid., paras 32-3 (OUP numbers). The Court's view on the domestic effect of the ICCPR seems inconsistent with the Court's own jurisprudence: see E. K. P. Aguilan, 'Analysis: ILDC 3005 (PH 2016)' (2019), para. A3.

34 Wilson v. Ermita, para. 34 (OUP numbers). 
The court's conclusion in Wilson v. Ermita is nothing new. Noteworthy still, however, is that the Supreme Court of the Philippines invoked the HRC's General Comment No. 33 in the course of denying the applicability of Views to case-specific judicial responses. In General Comment No. 33 (advanced unedited version of November 2008), the HRC regarded its Views as exhibiting 'some important characteristics of a judicial decision'. ${ }^{35}$ The Supreme Court quoted this phrase, observing that the HRC's Views 'only displays "important characteristics of a judicial decision". ${ }^{36}$ According to the court, the Views are thus 'mere recommendations to guide the State it is issued against. ${ }^{37}$ While the Supreme Court of the Philippines at least engaged with the narrative of General Comment No. 33, the court's use of the finding was rather ironic. Judges used it in order to dismiss, as opposed to augment, the judicial relevance of the Views of the HRC.

These examples again remind us of the structurally limited role of the judiciary in providing case-specific follow-up. ${ }^{38}$ Yet even outside casespecific circumstances, some domestic courts have much more 'distanced relations ${ }^{39}$ with UN treaty-monitoring bodies and have taken a dismissive attitude towards the relevance of their treaty interpretation. ${ }^{40}$ In some countries, judicial narrative accommodates little or no reference to treaty body findings. While the International Law Association's (ILA) Committee on International Human Rights Law and Practice (1997-2008) conducted extensive studies on judicial practices, the study could not specifically identify judicial references to the monitoring bodies in, among others, the countries of Francophone Africa or the Arab region. According to the 2004 Berlin report of the ILA Committee, there were no identifiable judicial practices in Bulgaria, Jordan, Egypt, Saudi Arabia, Colombia, Ecuador, Chile, Argentina, Malaysia, Singapore or Brunei. ${ }^{41}$ The absence

35

UNHRC, 'General Comment No. 33: The Obligations of States Parties under the Optional Protocol' (Advance unedited version, 5 November 2008) CCPR/C/GC/33, para. 11.

36 Wilson v. Ermita, para. 35 (OUP numbers) (emphasis added).

37 Ibid. Any responses to such recommendations are a matter to be determined by the legislative and executive branches of the government, the Supreme Court added - see para. 36 (OUP numbers).

38 See nn. 17-19 and accompanying text.

39 See Chapter 1.

${ }^{40}$ Kanetake, 'UN Human Rights Treaty Monitoring Bodies before Domestic Courts', 226-7.

${ }^{41}$ ILA, Committee on International Human Rights Law and Practice, 'Final Report on the Impact of Findings of the United Nations Human Rights Treaty Bodies' (2004) para. 29, $\mathrm{ft} 28$. 
of explicit reference is also evident in French courts. A study of French courts' practices suggests that not only judges, but also the litigants themselves rarely refer to the monitoring bodies' findings. ${ }^{42}$

\subsubsection{International Legal Justification for Non-engagement}

There are, no doubt, country-specific backgrounds that sustain and justify no or very limited judicial engagement with the findings of the monitoring bodies. ${ }^{43}$ Judges' strong loyalty to the separation of powers, for instance, may sustain distanced relations with formally non-binding international documents. ${ }^{44}$ What should be remembered, however, is that non-engagement can be explained and justified, not only by domestic specificities, but also by international law. A regularly invoked ground in this regard is the formalistic narrative that treaty body findings lack legal binding force. As a matter of formal status, it is hard to deny that Views themselves are not binding under international law. ${ }^{45}$ States generally consider that the HRC's Views, as well as interim measures, are non-binding under international law. ${ }^{46}$ The lack of binding force is even more evident with regard to General Comments and Concluding Observations.

The legal status of the findings themselves does not speak of the status of the content of the committees' findings. States, and indirectly their courts, are obliged to give effect to the substance of the findings of the treaty-monitoring bodies, if it reflects established treaty obligations. The content of General Comments and Views may reflect 'subsequent practice in the application of the treaty which establishes the agreement of the

${ }^{42}$ S. El Boudouhi and G. Dannenberg, 'France: Implementation of International Human Rights Decisions in France', in S. Kadelbach, T. Rensmann and E. Rieter (eds), Judging International Human Rights (Springer International Publishing, 2019) pp. 453-70, at p. 466.

${ }^{43}$ Kanetake, 'UN Human Rights Treaty Monitoring Bodies before Domestic Courts', 228-30.

${ }^{44}$ Ibid., 229-30.

45 See, e.g., 'Report of the International Law Commission, Seventieth Session (30 April-1 June and 2 July-10 August 2018)' (2018) UN GAOR, 73rd Sess., Supp. No. 10, UN Doc. A/73/10, 109, para. 7, fn 614; C. Tomuschat, 'Human Rights Committee', in R. Wolfrum (ed.), The Max Planck Encyclopedia of Public International Law (Oxford University Press, 2010), para. 14.

46 See van Alebeek and Nollkaemper, 'The Legal Status of Decisions by Human Rights Treaty Bodies', pp. 372-3, pp. 385-90. 
parties regarding its interpretation'. ${ }^{47}$ While, in principle, 'subsequent practice' is not equated with the institutional practices of the monitoring bodies themselves, the monitoring bodies' findings can facilitate an interpretation accepted by states parties which may support or acquiesce to the observations of the monitoring bodies, ${ }^{48}$ even though caution should be exercised.

Despite the content-based obligation on the part of states parties, the rule of treaty interpretation is so flexible that domestic courts can readily argue that the monitoring bodies' interpretation does not reflect 'subsequent practice'. The flexibility is preserved by the International Law Commission (ILC), which adopted, in 2018, a set of draft conclusions on 'subsequent agreements and subsequent practice in relation to the interpretation of treaties'. ${ }^{49}$ In the draft conclusions, the ILC reiterated that a pronouncement of 'expert treaty bodies', such as UN human rights treaty-monitoring bodies, ${ }^{50}$ 'may' give rise to, or refer to, a 'subsequent agreement or subsequent practice by parties' under Article 31(3) of the Vienna Convention on the Law of Treaties. ${ }^{51}$ The draft conclusions, however, warned that ' $[\mathrm{s}$ ]ilence by a party shall not be presumed to constitute subsequent practice' under Article 31(3)(b) of the Vienna Convention. ${ }^{52}$ As the ILC acknowledges, 'it cannot usually be expected that States parties take a position with respect to every pronouncement by an expert treaty body, be it addressed to another State or to all States generally ${ }^{53}$ While this caution against the misinterpretation of silence by states parties makes pragmatic sense, the ILC's work did not elaborate upon possible indicators with which to assess whether the pronouncement of UN human rights treaty-monitoring bodies reflects established treaty interpretation. Overall, the ILC's work preserved the

47 Vienna Convention on the Law of Treaties, 23 May 1969, in force 27 January 1980, 1155 UNTS 311, Article 31(3)(b).

48 ILA, 'Final Report on the Impact of Findings' (2004), para. 21; G. Ulfstein, 'Individual Complaints', in H. Keller, G. Ulfstein and L. Grover (eds), UN Human Rights Treaty Bodies: Law and Legitimacy (Cambridge University Press, 2012) pp. 73-115, at pp. $97-100$.

49 'Text of the Draft Conclusions on Subsequent Agreements and Subsequent Practice in Relation to the Interpretation of Treaties', see 'Report of the International Law Commission, Seventieth Session', 12-16.

50 'Report of the International Law Commission, Seventieth Session' above, 106 (Conclusion 13).

51 Ibid., 106 (Conclusion 13.3).

52 Ibid., 106 (Conclusion 13.2).

53 Ibid., 113, para. 19 (commentary regarding Conclusion 13.3). 
flexibility - and associated uncertainty - inherent in Article 31(3)(b) of the Vienna Convention on the Law of Treaties, which, in the context of the theme of this chapter, effectively leaves ample space for domestic courts to reject the obligatory nature of the specific content of the findings.

\subsection{Judicial Engagement}

\subsubsection{Domestic Courts' Practices}

While the lack of legally binding force may serve as a justification for non-engagement, some other domestic courts have shown greater willingness to refer explicitly to treaty body findings. General Comments, Concluding Observations and Views can be invoked to interpret the terms of relevant human rights treaties, which may ultimately be used to inform the construction of domestic (constitutional) provisions regarding fundamental rights. Admittedly, judges tend to be less hesitant in referring to treaty body findings in such countries as Canada, the UK, New Zealand and possibly some other common law countries. ${ }^{54}$ Yet judicial proximity to treaty body findings is by no means limited to jurisdictions with common law traditions.

There are abundant examples of judicial interpretive engagement. ${ }^{55}$ Among many others, for instance, the Israeli Supreme Court in Kav Laoved v. Interior Ministry (2011), in denying the constitutionality of the country's work permit procedure designed for female migrant workers, consulted the CEDAW's General Recommendations 21 (on equality in marriage and family relations) and 26 (on women migrant workers), as well as the CERD's General Recommendation 30 (on discrimination against non-citizens). ${ }^{56}$ Likewise, the Israeli Supreme Court in Adam v. Knesset (2014) invoked the Views of the HRC in order to

${ }^{54}$ Kanetake, 'UN Human Rights Treaty Monitoring Bodies before Domestic Courts', 226.

${ }^{55}$ Ibid.

56 'Kav LaOved' - Worker's Hotline and ors v. Ministry of Interior and ors, Original petition to the High Court of Justice, HCJ 11437/05, ILDC 2181 (IL 2011) (13 April 2011) (Israel, Supreme Court as High Court of Justice), paras H3-H4 (ILDC paragraph numbers). See CEDAW, 'General Recommendation No. 21: Equality in Marriage and Family Relations' (1994) UN Doc. A/49/38; CEDAW, 'General Recommendation No. 26 on Women Migrant Workers' (5 December 2008) CEDAW/C/2009/WP.1/R; CERD, 'General Recommendation 30 on Discrimination against Non-citizens' (2004) UN Doc. A/59/ $18,93$. 
interpret the scope of arbitrary arrest and detention under the ICCPR, which served ultimately to decide upon the constitutionality of domestic legislation. ${ }^{57}$

In a similar vein, the Federal Court of Australia in Iliafi v. The Church of Jesus Christ and the Latter-Day Saints Australia (2014) resorted to several findings of the monitoring bodies: General Recommendation No. 20 of the CERD, ${ }^{58}$ the HRC's General Comments Nos. 22 (on the right to freedom of thought, conscience and religion) and 23 (on the rights of minorities), ${ }^{59}$ and the jurisprudence of the HRC formulated through its Views. ${ }^{60}$ These documents were mentioned by the Australian court in order to interpret the Racial Discrimination Convention and the ICCPR, ${ }^{61}$ and, ultimately, to construe the Racial Discrimination Act 1975 of Australia. ${ }^{62}$ Interestingly, the Federal Court of Australia cited para. 66 of the ICJ's decision in Diallo, as well as Article 38(1)(d) of the ICJ Statute, in consulting the CERD's General Recommendation No. $20 .{ }^{63}$ Yet the court did not specify whether it intended to ascribe, as the ICJ did in paragraph 66 of Diallo, 'great weight' to the interpretation of the monitoring bodies. ${ }^{64}$

While there are abundant examples of judicial reference, the extent of substantive engagement varies depending on courts and judges. Illustrative in this regard is the comparison between UK and Canadian courts in a series of decisions concerning the interpretation of Article 14(1) of the

57 HCJ Infiltrators Case, Adam and Ors v. The Knesset and Ors, Original petition to the High Court of Justice, HCJ 7146/12, ILDC 2078 (IL 2013), 16 September 2013 (Israel, Supreme Court), paras H5-H6 (ILDC report by Nita Benoliel); Y. Shany, 'Israel', in F. M. Palombino (ed.), Duelling for Supremacy: International Law vs. National Fundamental Principles (Cambridge University Press, 2019) p. 167-83, at pp. 177-8.

58 Iliafi and Others v. The Church of Jesus Christ of Latter-Day Saints Australia [2014] FCAFC 26 (19 March 2014) (Federal Court of Australia), paras 62-4; CERD, 'General Recommendation 20: The Guarantee of Human Rights Free from Racial Discrimination' (1996) UN Doc. A/51/18 (1996), annex VIII, 124.

59 Iliafi, paras 66-7, 85, 96-9, 103; HRC, 'General Comment No. 22 (Art. 18)' (27 September 1993) CCPR/C/21/Rev.1/Add.4; HRC, 'General Comment No. 23: The Rights of Minorities (Article 27)' (26 April 1994) CCPR/C/21/Rev.1/Add.5.

${ }^{60}$ E.g., Iliafi, paras 100-1.

${ }^{61}$ International Convention on the Elimination of All Forms of Racial Discrimination, 21 December 1965, 660 UNTS 195, Art 5; International Covenant on Civil and Political Rights, 16 December 1966, 999 UNTS 171, Articles 18, 27.

62 Racial Discrimination Act 1975 (Australia), Act No. 52 of 1975 (11 June 1975), section 9.

${ }^{63}$ Iliafi, para. 62.

${ }^{64}$ Diallo, para. 66. 
Torture Convention. ${ }^{65}$ Both UK and Canadian courts disagreed with the CAT's interpretation of the provision that a civil remedy ought to be made available for all acts of torture, including those committed outside the forum state, ${ }^{66}$ by limiting the scope of state immunity. ${ }^{67}$

While both UK and Canadian courts disagreed with the CAT's treaty interpretation, there were differences in terms of the extent to which courts substantively engaged with the CAT's position. In the House of Lords, judges rather summarily dismissed the relevance the CAT in Jones v. Saudi Arabia (2006). ${ }^{68}$ Lord Bingham noted that ' $[w]$ hatever its value in influencing the trend of international thinking, the legal authority of the Committee's recommendation is slight'. ${ }^{69}$ In a similar vein, Lord Hoffmann found 'no value' in the Committee's position. ${ }^{70}$ The disagreement of UK judges in Jones was referred to by the Canadian Supreme Court in Kazemi (Estate) v. Iran (2014). ${ }^{71}$ The Canadian court, however, while disagreeing with the CAT's interpretation, took a few more steps to provide substantive explanations as to why judges did not agree with the CAT's interpretation.

In Kazemi, the Canadian Supreme Court admitted that 'the Committee's comments may be helpful for purposes of interpretation', ${ }^{72}$ by referring to its earlier decision in Suresh (2002) where the Supreme Court had consulted the CAT's position. ${ }^{73}$ Yet the majority of the Canadian Supreme Court noted that the Committee's

${ }^{65}$ Convention against Torture and Other Cruel, Inhuman or Degrading Treatment or Punishment, 10 December 1984, 1465 UNTS 85, Art. 14(1). See Kanetake, 'UN Human Rights Treaty Monitoring Bodies before Domestic Courts', 212-13.

${ }^{66}$ See, e.g., CAT, 'General Comment No. 3 (2012): Implementation of Article 14 by States Parties' (13 December 2012) CAT/C/GC/3, para. 22.

67 The CAT made it clear in its Concluding Observations addressed to Canada: CAT, 'Concluding Observations of the Committee against Torture: Canada' (25 June 2012) CAT/C/CAN/CO/6, para. 15; CAT, 'Concluding Observations on the Seventh Periodic Report of Canada' (21 December 2018) CAT/C/CAN/CO/7, para. 41.

68 Jones v. Saudi Arabia [2006] UKHL 26; (2007) 1 AC 270 (UK, House of Lords, 14 June 2006).

69 Ibid., para. 23 (Lord Bingham).

${ }^{70}$ Ibid., para. 57 (Lord Hoffmann). See also Jones and Others v. The United Kingdom, App. Nos. 34356/06 and 40528/06, Judgment of 14 January 2014, para. 208 (disagreeing with the CAT's interpretation).

${ }^{71}$ Kazemi (Estate) v. Islamic Republic of Iran 2014 SCC 62, [2014] 3 S.C.R. 176 (Canada, Supreme Court, Judgment of 10 October 2014), para. 148.

72 Ibid., para. 148.

73 Suresh v. Canada, (2002) 208 DLR (4th) 1 (2002) 124 ILR 343 (Canada, Supreme Court, 11 January 2002), para. 73; Kanetake, 'UN Human Rights Treaty Monitoring Bodies before Domestic Courts', 211. 
comments, 'despite their importance', 'should not be given greater weight than the pronouncements of states parties and judicial authorities. ${ }^{74}$ The court observed that the CAT's comments 'do not override adjudicative interpretations', such as those seen in Jones. ${ }^{75}$ 'At best', according to the highest court of Canada, the CAT's comments 'form part of a dialogue within the international community where no consensus has yet developed' on treaty interpretation. ${ }^{76}$ The majority's treatment of the CAT's remarks is contrasted with the narrative of Justice Abella in dissent. She observed that the CAT's 'expertise lends support to the weight of its interpretation', ${ }^{77}$ referring to the fact that the Committee had made critical remarks on Canadian legal practices. ${ }^{78}$ The narrative of the Canadian court was noteworthy in that the court explained how much weight it should give to the CAT's treaty interpretation. While judges in the majority substantively engaged with the CAT's position, the Supreme Court, at least in this specific case, regarded it as merely one of the opinions that the court may take into account.

\subsubsection{Normative Pathway: Authorization to Consider}

Domestic courts' discretionary reference to treaty body findings is no doubt conditioned by domestic sociological and legal contexts. At the same time, it must be once again noted that international law also explains and justifies domestic courts' discretionary engagement. Namely, states, and indirectly their courts, may consider the findings of $\mathrm{UN}$ human rights treaty-monitoring bodies as part of 'supplementary means of interpretation' under Article 32 of the Vienna Convention on the Law of Treaties. ${ }^{79}$

In fact, Article 32 of the Vienna Convention on the Law of Treaties has been mentioned by domestic courts in consulting treaty body findings. For example, in Minister for Immigration and Citizenship v. Anochie

74 Kazemi (2014), para. 147.

75 Ibid., para. 148.

76 Ibid.

77 Ibid., para. 224 (Justice Abella in dissent, agreeing with the Canadian Bar Association's remark).

78 Ibid., para. 226 (Justice Abella in dissent).

79 E.g., Y. Iwasawa, 'Domestic Application of International Law' (2016) 378 Recueil des Cours 236-7 (regarding Japanese courts' practices); Kanetake, 'UN Human Rights Treaty Monitoring Bodies Before Domestic Courts', 220-1. 
$(2012)^{80}$ before the Federal Court of Australia, the judge consulted the HRC's Views and General Comments Nos. 15 (on the position of aliens) and 31 (on the nature of the general obligation) ${ }^{81}$ in the process of interpreting Australia's non-refoulement obligations. The Federal Court explicitly elaborated upon the question of what materials the court may consult in interpreting the ICCPR. ${ }^{82}$ The judge accepted, 'upon reflection', that 'the Committee's interpretation of the ICCPR is admissible' in court for the interpretation of the treaty. ${ }^{83}$ The Federal Court suggested that its recourse to the HRC's interpretation was justified by Article 40(4) of the ICCPR and Article 1 of the Optional Protocol. ${ }^{84}$ Article 40(4) serves as a legal basis for the HRC to issue General Comments, ${ }^{85}$ while Article 1 of the Optional Protocol empowers the Committee to receive and consider individual communications. ${ }^{86}$ On this basis, according to the Federal Court, the Committee's Views and General Comments form part of 'supplementary means of interpretation' (under Article 32 of the Vienna Convention on the Law of Treaties). ${ }^{87}$ Equally, the Views and General Comments serve as 'subsidiary means for the determination of rules of law' (under Article 38(1)(d) of the Statute of the International Court of Justice) ${ }^{88}$

The characterization of treaty body findings as part of supplementary means leaves states (and their courts) to decide whether to consider a particular finding of the committees and how much weight states give to

${ }^{80}$ Minister for Immigration and Citizenship v. Anochie and Another [2012] FCA 1440, (2012) 209 FCR 497 (Australia, Federal Court, 18 December 2012). The subsequent decision did not refer to the Committee's findings: Anochie v. Minister for Immigration and Citizenship [2013] AATA 391 (Australia, Administrative Appeals Tribunal, 12 June 2013).

${ }^{81}$ UNHRC, 'General Comment No. 15: The Position of Aliens under the Covenant' (11 April 1986) HRI/GEN/1/Rev.9 (Vol. I); HRC, 'General Comment No. 31: Nature of the General Legal Obligation Imposed on States Parties to the Covenant' (29 March 2004) CCPR/C/21/Rev.1/Add.13.

82 Anochie, paras 40-50.

${ }^{83}$ Ibid., para. 45.

${ }^{84}$ Ibid., paras 45-6.

85 ICCPR, Article 40(4).

${ }^{86}$ Optional Protocol to the International Covenant on Civil and Political Rights, 16 December 1966, 999 UNTS 302, Article 1. The Federal Court also noted the fact that the HRC's Views are forwarded to the individual and the state party concerned, according to Article 5(4) of the Optional Protocol.

${ }^{87}$ Anochie, para. 48. This is based on the Federal Court's earlier case: Minister for Immigration and Multicultural and Indigenous Affairs v. Al Masri (2003) 126 FCR 54, para. 148 .

88 Ibid., para. 49. 
the committees' interpretation. In the aforementioned Anochie, the Australian court noted that, given that the members of the HRC were supposed to be 'persons of high moral character and recognized competence in the field of human rights, ${ }^{89}$ the HRC's output may form part of the 'teachings of the most highly qualified publicists' under Article $38(1)(d)$ of the ICJ Statute. ${ }^{90}$ On this basis, the Federal Court quoted para. 66 of the ICJ's judgement in Diallo, in which the ICJ found that it 'should ascribe great weight' to the interpretation of the Committee. ${ }^{91}$

\subsection{Beyond Discretionary Judicial Engagement}

\subsubsection{Domestic Courts' Practices}

As noted in Section 6.4, states, and indirectly their courts, are authorized under international law to consider the findings of UN human rights treaty-monitoring bodies. At the same time, the survey of domestic court decisions ${ }^{92}$ indicates the existence of normative expectations beyond mere discretionary consideration. Some courts referred to a normative expectation to consider, both in and outside the context of case-specific responses to Views on individual communications.

For instance, in the Jamaican case of Lewis (2000), ${ }^{93}$ the Judicial Committee of the Privy Council observed that the HRC's Views should be considered in case-specific contexts. The Lewis case involved appellants who had been sentenced to death by the Jamaican courts and had petitioned the HRC. According to the Privy Council, '[w]hen the report of the international human rights bodies is available that should be considered and if the Jamaican Privy Council do [sic] not accept it [then] they should explain why. ${ }^{94}$ This observation is significant, in that the Privy Council found it necessary, not merely to consider Views, but also to provide explanation in case of disagreement. The Dutch Administrative High Court in its decision of July 2006 seems to have given an even stronger assertion in favour of Views. The Court regarded

89 ICCPR, Article 28(2).

90 Anochie, para. 49.

${ }^{91}$ Ibid. See n. 64 and accompanying text.

92 See $\mathrm{n} .1$ on the scope of the research on which the chapter is based.

93 Lewis v. Attorney General of Jamaica (2000) 134 ILR 615 (Jamaica, Judicial Committee of the Privy Council, 12 September 2000).

${ }^{94}$ Ibid., 635. 
the Views of the HRC as non-binding, yet still 'authoritative', and noted that national courts could only deviate from the Views if justified by 'compelling reasons'. ${ }^{95}$

These instances of judicial respect for Views do not alter the fact that domestic courts have a limited role in taking case-specific follow-up measures. ${ }^{96}$ In this sense, it is much more relevant to see how domestic courts navigate their pathways to the monitoring bodies outside casespecific contexts. Some judges were willing to indicate the existence of normative expectations - if not a strict obligation - for domestic courts to engage with the monitoring bodies' interpretation when the courts interpret relevant treaty provisions. For instance, the Colombian Constitutional Court in 2004 characterized the CESCR as an 'authorized interpreter' of the Covenant. ${ }^{97}$ In the Test Trial Fund Clara Wichmann case of 2005, the Dutch court noted that the CEDAW is empowered to issue General Recommendations and that such Recommendations should be taken into account in the context of interpreting the Convention..$^{98}$ In 2007, the Belize Supreme Court in the case of Cal noted that, given Belize's commitments under the Racial Discrimination Convention, the government 'should take this communication [country-specific Correspondence] seriously and respond accordingly'. ${ }^{99}$

Another noteworthy example is the German Federal Constitutional Court's engagement with the CRPD's Concluding Observations and General Comments in the Order of 26 July $2016{ }^{100}$ The case involved the provision of medical treatment to a woman against her natural will in circumstances where she suffered from mental and physical illnesses and was deemed unable to provide consent. The Federal Constitutional Court

95 Appellante v. de Raad van Bestuur van de Sociale Verzekeringsbank, 21 July 2006, LJN: AY5560 (the Netherlands, Central Appeals Tribunal); cited in van Alebeek and Nollkaemper, 'The Legal Status of Decisions by Human Rights Treaty Bodies', p. 402, fn 199.

96 See nn. 17-19 and accompanying text on the principle of res judicata. In this vein, see, e.g., $X$ v. Council of Ministers, paras 41, 43 (OUP numbers).

97 Decision No T-025 of 2004 (2004) (Constitutional Court, Colombia, 22 January 2004, English translation www.brookings.edu), para. 8.3.2 ('como intérprete autorizado del Pacto sobre la materia').

98 Test Trial Fund Clara Wichmann (Stichting Proefprocessenfonds Clara Wichmann) and Ors v. Netherlands, First instance decision (2005) HA ZA 03/3395, LJN: AU2088, ILDC 221 (NL 2005) (the Netherlands, District Court, 7 September 2005), para. 3.18.

99 Cal v. Attorney-General (2007) 71 WIR 110; 135 ILR 77 (Belize, Supreme Court, 18 October 2007), para. 125.

100 German Federal Constitutional Court (BVerfG), Order of the First Senate of 26 July 2016, 1 BvL 8/15 (English translation www.bverfg.de/e/ls20160726_1bvl000815en.html). 
obliged the legislature to enact laws to allow coercive medical treatment in such cases. In holding that coercive treatment was compatible with the Convention on the Rights of Persons with Disabilities, the German court effectively disagreed with the CRPD's General Comment No. 1, Concluding Observations on Germany, and Guidelines on Article 14, in which the CRPD had criticized the practices of custodianship and forced treatment for failing to respect disabled persons' autonomy and will. ${ }^{101}$ According to the Constitutional Court, these CRPD documents do not address the critical scenario involving persons who cannot form a free will. ${ }^{102}$ While the German Federal Constitutional Court took a critical look at the CRPD's observations, the court substantively engaged with the Committee's position. Furthermore, the court notably observed that a national court, although it is not obliged to follow the CRPD, ${ }^{103}$ should deal with the CRPD's opinions 'in an argumentative way and in good faith ${ }^{104}$ - as the German court seems to have done in this specific instance.

\subsubsection{Normative Pathway: An Obligation to Consider and Its Variations}

The aforementioned judicial narratives - such as those in Test Trial Fund Clara Wichmann in the Netherlands, Cal in Belize and the Order of 26 July 2016 in Germany - are nuanced. By no means do they elucidate an obligation to consider or give due consideration to certain types of findings. Yet the courts' nuanced position ought to be understood in light of some of the limitations extant at the national level for domestic courts visà-vis legislative and executive bodies. ${ }^{105}$ Normative expectations expressed by judges cannot be separate from a contested obligation to consider, incumbent on states parties themselves. In discussing such an obligation, it is necessary to distinguish different types of treaty body findings.

101 CRPD, 'General Comment No. 1 (2014), Article 12: Equal Recognition Before the Law' (19 May 2014) CRPD/C/GC/1, para. 26; CRPD, 'Concluding Observations on the Initial Report of Germany' (13 May 2015) CRPD/C/DEU/CO/1, paras 25-6; CRPD, 'Guidelines on Article 14 of the Convention on the Rights of Persons with Disabilities: The Right to Liberty and Security of Persons with Disabilities' (September 2015), paras $11-12$.

102 German Federal Constitutional Court, 1 BvL 8/15, para. 91.

103 Ibid., para. 90.

104 Ibid., para. 90.

105 See nn. 17-19 and accompanying text. 


\subsubsection{Case-Specific Responses to Views}

With regard to the case-specific responses to Views, it is hard to deny the existence, under international law, of such an obligation to consider. In fact, some treaties explicitly provide such an obligation. With regard to the CEDAW, Article 7(4) of the Optional Protocol obliges a state party to 'give due consideration to the views of the Committee' and to submit within six months the state's follow-up action. ${ }^{106}$ These dual obligations (to give due consideration and to provide information on follow-up action) are also explicitly laid down in regard to the Views of the CESCR $^{107}$ and the CRC. ${ }^{108}$

The language is less explicit when it comes to the HRC. Yet the ICCPR's Optional Protocol, adopted in 1966, at least obliges a state party to submit information in response to the Views. ${ }^{109}$ On top of the explicit requirement, there is an obligation to cooperate with a committee, which is applicable to all the monitoring bodies, including the HRC. Such an obligation is based on the general obligation to perform a treaty in good faith, under Article 26 of the Vienna Convention on the Law of Treaties, ${ }^{110}$ accompanied by states parties' recognition of the competence of the committees under relevant human rights treaties. While the meaning of 'good faith' is no doubt contextual, ${ }^{111}$ the good faith obligation has been understood as an obligation to cooperate with the committees, as the HRC remarked in General Comment No. $33 .{ }^{112}$ Cooperation does not amount to require compliance; yet a state party may be acting in bad faith towards its treaty commitment if frequent non-compliance is combined with the failure to attempt to seriously engage with Views. ${ }^{113}$

106 Optional Protocol to the Convention on the Elimination of All Forms of Discrimination against Women, 6 October 1999, 2131 UNTS 83, Article 7(4).

107 Optional Protocol to the International Covenant on Economic, Social and Cultural Rights, 10 December 2008, UN Doc. A/63/435, Article 9(2).

108 Optional Protocol to the Convention on the Rights of the Child on a communications procedure, 19 December 2011, UN Doc. A/RES/66/138, Article 11(1).

109 Optional Protocol to the ICCPR (n 86).

110 VCLT, Article 26.

111 See R. Kolb, Good Faith in International Law (Hart Publishing, 2017), pp. 166-9.

112 UNHRC, 'General Comment No. 33: The Obligations of States Parties under the Optional Protocol' (25 June 2009) CCPR/C/GC/33, para. 15. Cf. UNHRC, 'Draft General Comment No 33 (Second Revised Version as of 18 August 2008)' (25 August 2008) CCPR/C/GC/33/CRP.3, para. 16.

113 S. Joseph, 'Committees: Human Rights Bodies', in R. Wolfrum (ed.), The Max Planck Encyclopedia of Public International Law (Oxford University Press, 2010), para. 9. 
It is readily possible to find statements by states parties that they owe an obligation to take into account the Views addressed to them. ${ }^{114}$ Iceland, for instance, expressed its position in a series of actions following the HRC's Views in Haraldsson et al. v. Iceland in October 2007 regarding the fisheries management system. ${ }^{115}$ According to the Icelandic government, Iceland 'elected to become a party' to the Optional Protocol to the ICCPR, 'thereby recognising the competence of the Human Rights Committee to decide whether there has been a violation of the provisions of the Covenant or not'. ${ }^{116}$ On this basis, Iceland noted that it is 'therefore required by international law to address the conclusions of the Committee. ${ }^{117}$ Not surprisingly, the government still preserved the space for discretion, adding that the Views in question were not detailed enough. According to Iceland, the Views 'do not include a summarized conclusion in the form of an adjudication, but a general discussion' without 'detailed guidance as to the precise measures required'. ${ }^{118}$ In short, Iceland is acknowledging an obligation to consider and respond to Views, while, at the same time, characterizing them as 'a general discussion'. ${ }^{119}$

There are also some influential academic writings that support the existence of the obligation to consider with regard to states parties' casespecific responses to Views. Tomuschat articulated that 'States Parties cannot simply ignore' the Views of the HRC, despite the fact that they

114 See van Alebeek and Nollkaemper, 'The Legal Status of Decisions by Human Rights Treaty Bodies', p. 386.

115 UNHRC, Erlingur Sveinn Haraldsson and Örn Sncevar Sveinsson v. Iceland, Communication No. 1306/2004, CCPR/C/91/D/1306/2004 (14 December 2007). The communication concerned discrimination in the business of commercial fishing quotas. See G. Gauksdottir and T. Ingadottir, 'Compliance with the Views of the UN Human Rights Committee and the Judgments of the European Court of Human Rights in Iceland', in A. Eide, J. T. Möller and I. Ziemele (eds), Making Peoples Heard: Essays on Human Rights in Honour of Gudmundur Alfredsson (Nijhoff, 2011) pp. 511-36, at pp. 526-9.

116 Letter from the government of Iceland concerning the Views adopted by the Human Rights Committee on 24 October 2007, cited in Gauksdottir and Ingadottir, 'Compliance with the Views of the UN Human Rights Committee', pp. 530-1.

117 Ibid., p. 531.

118 Ibid., p. 531.

119 Ibid. Iceland's readiness to review its system has led the HRC to close the follow-up examination of the case: 'Report of the Human Rights Committee, Volume I, 103rd Session (17 October-4 November 2011), 104th Session (12-30 March 2012)', (2012) UN Doc. A/67/40 (Vol. I), at 114-15 (with a finding of a partly satisfactory implementation of the recommendation). 
lack legally binding force. ${ }^{120}$ States parties 'have to consider' the Views 'in good faith (bona fide)'. ${ }^{121}$ Tomuschat observes that states' lack of reaction 'would appear to amount to a violation of the obligations under the ICCPR'. ${ }^{122}$ By quoting Tomuschat's remarks, the Venice Commission reiterated that 'member states are under the obligation to take the HRC's final views into consideration in good faith'. ${ }^{123}$

A main point of contestation remains the extent to which the obligation to consider in good faith requires states parties, and indirectly their courts, to favour the monitoring bodies' treaty interpretation. According to Tomuschat, states parties have to 'carefully examine' the Views addressed to them, and that 'there exists a presumption in favour of substantive correctness of such views'. ${ }^{124}$ In case of disagreement, a state party 'must present detailed observations specifying its counter-arguments'. ${ }^{125} \mathrm{An}$ observation of a similar nature to the one by Tomuschat was relied upon by the Privy Council, in the New Zealand case of Tangiora in 1999, which found the HRC's Views hard to dismiss despite the lack of binding force. ${ }^{126}$ According to the Privy Council, the Views of the HRC acquire 'authority from the standing of its members and their judicial qualities of impartiality, objectivity and restraint'. ${ }^{127}$ Moreover, the Privy Council suggested that the functions of the Committee are 'adjudicative', as it makes a definitive and final ruling which is determinative of an issue that has been referred to it. ${ }^{128}$ Despite these statements, however, the basis of the presumption of substantive correctness remains unclear.

\subsubsection{Outside Case-Specific Responses}

It has been further argued that the obligation to consider is not limited to states' case-specific follow-up to the Views addressed to them. In the

120 Tomuschat, 'Human Rights Committee', para. 14.

121 Ibid.

122 Ibid.

123 European Commission for Democracy through Law (Venice Commission), 'Report on the Implementation of International Human Rights Treaties in Domestic Law and the Role of Courts' adopted by the Venice Commission at its 100th plenary session (Rome, 10-11 October 2014), CDL-AD(2014)036 (8 December 2014), para. 78.

124 Christian Tomuschat, Human Rights: Between Idealism and Realism (Oxford University Press, 2014), p. 267.

125 Ibid.

126 Tangiora v. Wellington District Legal Services Committee (1999) [2000] 1 WLR 240; 124 ILR 570 (New Zealand, Judicial Committee of the Privy Council, 4 October 1999).

127 Ibid., 575.

128 Ibid. 
commentary to its draft conclusions adopted in 2018, the ILC acknowledge that 'State parties may have an obligation, under a duty to cooperate under certain treaties, to take into account and to react to a pronouncement of an expert treaty body ${ }^{129}$ where the pronouncement is 'specifically addressed to them or to individual communications regarding their own conduct. ${ }^{130}$ The ILC's commentary signals that the dual obligations to consider and react may be applicable, not only to Views, but also to Concluding Observations addressed to a specific state party. The 2016 Final Report of the ILA International Human Rights Law Committee may have even gone beyond the ILC's suggestion. According to the Final Report, the 'jurisprudence' developed by human rights bodies 'constitutes res interpretata within the treaty system accepted by the state. ${ }^{131}$ On this basis, the ILA's Final Report observed that domestic courts implement the good faith obligation by 'giving serious consideration' to the decisions of human rights bodies. ${ }^{132}$ The ILA's Final Report indicated that the treaty bodies' 'jurisprudence' - and not necessarily limited to Views in case-specific follow-up - ought to be considered seriously.

It seems plausible to argue that states parties' obligation to cooperate with the committees, based on the obligation to perform a treaty in good faith, ${ }^{133}$ is applicable to Concluding Observations as they are addressed to specific states. One cannot be certain, however, whether this obligation is applicable to General Comments. Further contested is whether the presumption of substantive correctness applies to findings outside casespecific follow-up to Views. In para. 66 of Diallo, the ICJ was prepared to accord 'great weight' to the HRC's 'interpretation' or 'jurisprudence' in general. ${ }^{134}$ Interestingly, the ICJ's justification for doing so was not only because the Committee is the independent body that was established specifically to supervise the application of that treaty [i.e. the ICCPR]'. ${ }^{135}$

\footnotetext{
129 'Report of the International Law Commission, Seventieth Session' above, p. 113, para. 19 (commentary regarding Conclusion 13.3) (emphasis added).

130 Ibid. (emphasis added).

131 S. Kadelbach, 'The Domestic Implementation of Judgments/Decisions of Courts and Other International Bodies That Involve International Human Rights Law: Final Report of the ILA International Human Rights Law Committee (Part 2)', in S. Kadelbach, T. Rensmann and E. Rieter (eds), Judging International Human Rights (Springer International Publishing, 2019) pp. 51-100, at pp. 70-1.

132 Ibid., p. 71.

133 See nn. 110-113 and accompanying text.

134 See Diallo, para. 66.

135 See ibid.
} 
The ICJ ascribed great weight to the HRC's interpretation, also because of the wider interests at stake in achieving 'the necessary clarity and the essential consistency of international law, as well as legal security' necessary for the rights holders and duty bearers. ${ }^{136}$ The reasoning of the ICJ shows that the degree of normative weight to be given to treaty body findings relies not only on one's understanding of the characteristics of the monitoring bodies, but also the wider role that one wishes to ascribe to the bodies within the international legal order.

\subsection{Engagement and Acceptance}

\subsubsection{Domestic Courts' Practices}

In contrast with the nuanced engagement of domestic courts with UN human rights treaty-monitoring bodies, the Spanish Supreme Court in its judgement of July 2018 (Judgment No. 1263/2018) has taken a different and dichotomous path. ${ }^{137}$ In this exceptional yet significant case, the Spanish highest court established the binding character of the Views of the CEDAW at the domestic level. The Supreme Court's decision came after many years of legal battles by the appellant, González Carreño. ${ }^{138}$ Having been subject to physical and psychological violence by her partner, González Carreño filed a number of complaints in order to bring the abuses to the attention of the Spanish authorities. ${ }^{139}$ While local courts took some measures to protect the appellant, they did not fully take into account the risks that her partner could pose, not only to the appellant, but also to her daughter, Andrea. ${ }^{140}$ In May 2002, a Spanish local court allowed the partner, with respect to whom the appellant had obtained an order of marital separation, to visit their daughter Andrea without supervision. ${ }^{141}$ In April 2003, during the scheduled visit, the daughter was shot by her father who eventually killed himself.

136 See ibid.

137 Judgment No. 1263/2018 of 17 July 2018, ROJ: STS 2747/2018, ECLI: ES:TS:2018:2747 (Tribunal Supremo [Supreme Court], Sala de lo Contencioso-Administrativo [Contentious-Administrative Chamber]) (Spain). For detailed analysis, see $M$. Kanetake, 'María de los Ángeles González Carreño v. Ministry of Justice' (2019) 113 American Journal of International Law 586-92.

138 For facts, see CEDAW, Angela González Carreño v. Spain, Communication No. 47/2012 (16 July 2014), paras 2.1-2.21.

139 Ibid., para. 2.5.

140 See, e.g., ibid., para. 2.12.

141 Ibid., para. 2.13 . 
After the tragic incident, González Carreño went through a series of domestic court proceedings, trying to prove the pecuniary liability of the state which failed to protect her and her late daughter. From April 2004 to October 2010, her liability claims met rejection four times before Spanish courts. ${ }^{142}$ Her constitutional claim was likewise rejected by the Constitutional Court in April 2011. ${ }^{143}$ Having exhausted domestic remedies, on 19 September 2012, González Carreño brought her petition to the CEDAW. The Committee rendered its Views on 16 July 2014, finding the Spanish government in violation of her Conventional rights. ${ }^{144}$ Having found a violation of the state's obligations under the Convention, ${ }^{145}$ the Committee recommended Spain to provide compensation and conduct an exhaustive and impartial investigation. ${ }^{146}$ At the domestic level, however, the CEDAW's recommendations in July 2014 did not result in any changes to the situation of the appellant. A year later, in July 2015, the CEDAW still expressed its concern about the 'lack of follow-up to the Committee's views' on the part of the state party regarding González Carreño. ${ }^{147}$ Meanwhile, she launched a series of new administrative and judicial proceedings, ultimately before the Supreme Court, requesting the government to give effect to the CEDAW's Views. ${ }^{148}$

In its judgement of 17 July 2018, the Spanish Supreme Court regarded the Views of the CEDAW as binding at the domestic level, ordering the government to pay $€ 600,000$ for moral damages suffered by the appellant. ${ }^{149}$ The Supreme Court reached such a conclusion on the basis of both international and domestic laws. With regard to the international legal basis, the Spanish court held that the Views of the CEDAW have a 'binding/obligatory' character. ${ }^{150}$ The court ascribed such a character to Views, despite its acknowledgement that the CEDAW Convention does not oblige states parties to adopt any specific procedures in order to give

142 Ibid., paras 2.18-2.20.

143 Ibid., para. 2.21.

144 Ibid., para. 10.

145 CEDAW, Angela González Carreño, para. 10 (Articles 2(a-f), 5(a) and 16(1)(d) of the CEDAW Convention).

146 Ibid., para. 11(a).

147 CEDAW, 'Concluding Observations on the Combined Seventh and Eighth Periodic Reports of Spain' (29 July 2015) CEDAW/C/ESP/CO/7-8, paras 10-11.

148 See further Kanetake, 'María de los Ángeles González Carreño', 588-9.

149 Judgment No. 1263/2018 of 17 July 2018, 14.

150 Ibid., 12. 
effect to Views. ${ }^{151}$ The court derived the 'binding/obligatory' character on the basis of Article 24 of the CEDAW Convention and Articles 7(4) and 1 of the Optional Protocol. ${ }^{152}$

The Supreme Court's reasoning was further supported by domestic law. The court reiterated that the CEDAW Convention, on which the Committee and its Views are based, forms part of the domestic legal order under Article 96 of the Spanish Constitution. ${ }^{153}$ Pursuant to Article 10(2) of the Constitution, fundamental rights shall be interpreted in accordance with human rights treaties ratified by Spain. ${ }^{154}$ An important aspect of the court's reasoning was the manner in which the court invoked Article 9(3) of the Spanish Constitution. The provision guarantees 'the principle of legality and the normative hierarchy', according to which international obligations relating to the execution of the decisions of the CEDAW form part of the Spanish internal order and enjoy a hierarchical position above ordinary domestic law. ${ }^{155}$ On this basis, the Supreme Court observed that the Convention and the Views 'can and should be a decisive element' in proving the possible infringement of the fundamental rights of the appellant. ${ }^{156}$ While the Supreme Court emphasized the particularities of the appellant's case, the court took the position that the CEDAW's Views must be considered as a 'valid basis' for bringing a claim concerning the pecuniary liability of the state. ${ }^{157}$ Otherwise, as articulated by the Supreme Court, the 'absence of a specific procedure for executing' the Views of the Committee constitutes in itself a breach of a legal and constitutional mandate by Spain'. ${ }^{158}$

The Spanish Supreme Court's reasoning pertains only to the CEDAW's Views on individual communications, and not to other types of findings. Yet it would be good to reiterate once again that each monitoring body engages with its own previous findings. In the CEDAW's Views in Angela González Carreño v. Spain, the Committee's

151 Ibid., 12.

152 Ibid., 12.

153 See ibid., 12.

154 Ibid., 12.

155 Ibid., 12. It must be noted that international obligations are superior to ordinary domestic law - but not above the Constitution - based on Articles 95 and 96 of the Constitution, instead of Article 9(3) itself.

156 Ibid., 12.

157 Judgment No. 1263/2018 of 17 July 2018., 13.

158 Ibid., 13. 
reasoning built on its General Recommendation No. 19 (1992), ${ }^{159}$ in which the CEDAW had made it clear that states ought to act with due diligence to prevent violations involving the acts of private persons. ${ }^{160}$ In Angela González Carreño v. Spain, the Committee found the violations of the Convention, 'read jointly with ... general recommendation No. 19 of the Committee'. ${ }^{161}$ In other words, by according legal binding effect to Views, the Spanish Supreme Court in the judgement of July 2018 augmented the normative relevance of other CEDAW findings at the domestic level.

\subsubsection{Normative Pathway: An Obligation to Comply}

The Spanish Supreme Court's identification of the binding character of the Views of the CEDAW resembles the draft version of the HRC's General Comment No. 33 concerning the general obligations of states parties. In an early draft of what became the HRC's General Comment No. 33, the HRC characterized its role as an 'authentic interpreter' of the Covenant ${ }^{162}$ and regarded its Views as exhibiting 'most of the characteristics of a judicial decision'. ${ }^{163}$ Also, in the draft version, the HRC translated the obligation to cooperate with the Committee as entailing 'an obligation to respect the views of the Committee in the given case'. ${ }^{164}$ The HRC is not the only body that attempted to put forward an imperative tone. Within the CAT, one of its members observed that, ' $[w]$ hile the Committee's decisions were not strictly mandatory, States parties had an obligation to comply with them in good faith', which also justifies the CAT's follow-up mechanism. ${ }^{165}$

159 CEDAW, 'General Recommendation No. 19: Violence against Women’ (1992).

160 Ibid., para. 9.

161 CEDAW, Angela González Carreño, para. 10.

162 UNHRC, 'Draft General Comment No 33', para. 14 ('the [an] authentic interpreter'). See, further, Kanetake, 'UN Human Rights Treaty Monitoring Bodies Before Domestic Courts', 205-6.

163 UNHRC, 'Draft General Comment No 33', para. 11. On differences between the adoption of Views and judicial decision making, see, e.g., L. S. Borlini and L. Crema, 'The Legal Status of Decisions by Human Rights Treaty Bodies: International Supervision, Authoritative Interpretations or Mission Éducatrice?' (2019) 18 Global Community Yearbook of International Law and Jurisprudence, section III C.

164 Ibid., 'Draft General Comment No 33', para. 16.

165 CAT, 'Thirty-Sixth Session, Summary Record of the 717th Meeting' (1 June 2006) CAT/ C/SR.717, para. 65 (Mr. Mariño Menéndez, emphasis added). The remarks were also endorsed by the chairperson: see para. 66 (Mr. Mavrommatis). 
The imperative vocabularies used in the draft version of General Comment No. 33 met with criticisms from several states parties. ${ }^{166}$ In the end, the wording of the final version of General Comment No. 33 was revised, including the critical phrase 'authentic interpreter'. ${ }^{167}$ The draft version of General Comment No. 33 was an attempt to creatively translate a procedural duty to cooperate with the Committee, based on the good faith obligation, into the substantive obligation to respect the Views of the HRC. ${ }^{168}$ Such an attempt was not successful in 2008, at least in the context of the HRC.

In the judgement of July 2018, the Spanish Supreme Court by no means characterized the CEDAW as an authentic interpreter. In fact, the Spanish Constitutional Court reiterated in 2002 that the HRC was not a judicial organ and that the Views of the HRC could not represent the 'authentic interpretation' of the ICCPR. ${ }^{169}$ The crux, however, is that the Spanish Supreme Court's reasoning in 2018 was in part based on the state party's obligation to take Views seriously. The Spanish court referred to not only Article 24 of the Convention, according to which states parties 'undertake to adopt all necessary measures at the national level aimed at achieving the full realization of the rights recognized in the present Convention'. ${ }^{170}$ The Court also relied on Article 7(4) of the Optional Protocol, according to which the state party has dual obligations. Namely, the party 'shall give due consideration to the views of the Committee, together with its recommendations' and 'shall submit to the Committee, within six months, a written response'. ${ }^{171}$ As noted in Section 6.5.2.1, these dual obligations are enunciated for the CESCR and the CRC as well. ${ }^{172}$ Overall, the reasoning of the Spanish highest

166 Kanetake, 'UN Human Rights Treaty Monitoring Bodies before Domestic Courts', 205-6.

167 UNHRC, 'Draft General Comment No 33', para. 14; UNHRC, 'General Comment No. 33', para. 13. Regarding the distinction between authentic and authoritative interpretation, see Iwasawa, 'Domestic Application of International Law', 239-41.

168 UNHRC, 'Draft General Comment No 33', para. 16.

169 PM v. Criminal Chamber of the Supreme Court, Constitutional Appeal (recurso de amparo), ILDC 1794 (ES 2002), STC 70/2002, para. 7 of the section on legal foundations (Spain, Constitutional Court, 3 April 2002) ('Dictámenes no pueden constituir la interpretación auténtica del Pacto'). The Constitutional Court's narrative was reproduced by the Spanish Supreme Court in its judgment of 8 June 2015: Judgment of the Supreme Court of 8 June 2015 (Spain, Supreme Court, Third Chamber, ContentiousAdministrative), https://supremo.vlex.es/vid/575807258.

170 Judgment No. 1263/2018 of 17 July 2018, 12; CEDAW Convention, Article 24.

171 Optional Protocol CEDAW, Article 7(4).

172 See nn. 107-108. 
court demonstrates the breadth of what can be offered through the obligation to consider. After the lengthy administrative and judicial proceedings involving the victim of the state's neglect, the obligation to consider has reached the point where no further deliberation may be welcome.

\subsection{Conclusion}

The shortcomings of human rights protection at the domestic level have sustained the need for institutional mechanisms at the international level that monitor and assist states' implementation of human rights treaties. The ten human rights treaty-monitoring bodies, within their significantly limited resources, actively adopt general and specific findings. Each treaty-monitoring body generates and reiterates its own interpretation of relevant treaty obligations by cross-referencing previous findings. Despite the accumulation of instruments adopted, the effectiveness of treaty body findings ultimately relies on the degree to which their treaty interpretation becomes entangled with the practice of states parties, including their judiciary.

As illustrated by some examples discussed in this chapter, the treaty interpretation built by UN human rights treaty-monitoring bodies has been intertwined with the discourse of domestic court decisions. Various courts have shown their willingness to take into account General Comments, Concluding Observations and Views in the course of interpreting applicable human rights treaties and relevant domestic legal provisions. Judges' proximity to the international monitoring bodies varies, depending on sociological contexts in which judges have been situated. If UN treaty-monitoring bodies are not integrated in judges' legal training, it may be unrealistic to expect them to see the relevance of treaty body findings.

At the same time, a connecting point between UN treaty-monitoring bodies and domestic courts can also be normative, at least in part. One such normative pathway which generates 'discursive entanglement ${ }^{\text {'173 }}$ is the obligation to consider. As illustrated in the present chapter, there are a number of variations surrounding such an obligation, from mere encouragement to take into account to an obligation to implement. While normative expectations may be limited to certain types of treaty

173 See Chapter 1. 
body findings, the monitoring bodies regularly refer back to General Comments in drafting Concluding Observations or Views, reminding a state party of the monitoring bodies' earlier remarks on which specific observations are built. In other words, the consideration of Views would substantively involve a state party's reflection of General Comments or Concluding Observations.

Pathways built around the obligation to consider are not single routes. There are multiple normative variations: ranging from a cursory look, to substantive and reasoned engagement, to legally obliged acceptance. Due to the fact that there are multiple possibilities, judges' willingness to substantively engage with the treaty body's interpretation can be altered, for instance, by the initiatives to better ensure independence and impartiality of UN treaty-monitoring bodies. ${ }^{174}$ Substantive engagement on the part of domestic courts creates further opportunities for the treaty bodies to tailor their approaches to states parties. Deliberative space involving domestic courts and the monitoring bodies may be multifaceted and changeable, in that it allows various degrees of entanglement on the part of domestic courts. Yet it is precisely because of its precariousness that there arises the need for constant attempts to augment the quality of engagement, both on the part of domestic courts and UN treatymonitoring bodies.

174 E.g., 'Guidelines on the Independence and Impartiality of Members of the Human Rights Treaty Bodies ("the Addis Ababa Guidelines")' (2 August 2012) UN Doc. A/67/ 222 Annex I. 